\title{
Antidiabetic and Anti-hyperlipidemic Effects of Virgin Coconut Oil in Rats
}

\author{
Mona Abd-Elzaher El-Shemy \\ Department of Clinical Pathology, Faculty of Veterinary Medicine, Benha University, \\ Egypt.
}

\begin{abstract}
$\mathbf{V}$ IRGIN coconut oil is known to have beneficial health effects. Although it is rich in saturated fatty acids, these saturated fatty acids are easily absorbed and used as energy for metabolism and protects the body from disease. So, this study is designed to evaluate the protective effects of virgin coconut oil against alloxan induced diabetes.

In this study, forty male Wistar rats were divided into four groups (10 rats per group), control group, virgin coconut oil (VCO) group, alloxan group and alloxan treated group. Alloxan was administered at $150 \mathrm{mg} / \mathrm{kg}$ body weight through a single intraperitoneal injection. After three days of induction of diabetes by alloxan, virgin coconut oil was administered orally at $10 \mathrm{ml} / \mathrm{kg}$ body weight, daily for four weeks.

Results showed that alloxan caused diabetes as indicated by significant increase in the fasting blood glucose level $(330 \pm 2.8 \mathrm{mg} / \mathrm{dl})$ and oral glucose tolerance test with a significant reduction in serum insulin level $(0.90 \pm 0.05 \mu \mathrm{iu} / \mathrm{ml})$. Moreover, alloxan induced significant increase in total cholesterol $(110 \pm 2.8 \mathrm{mg} / \mathrm{dl})$, triglycerides $(350 \pm 7.05 \mathrm{mg} / \mathrm{dl})$ and LDL $(33.60 \pm 0.98 \mathrm{mg} /$ dl). Alloxan also induced renal dysfunction as indicated by a significant increase in serum creatinine $(3.25 \pm 0.02 \mathrm{mg} / \mathrm{dl})$ and urea $(76.14 \pm 0.64 \mathrm{mg} / \mathrm{dl})$. Alloxan caused significant elevations in ALT $(108.2 \pm 1.06 \mathrm{U} / \mathrm{L})$ and AST $(118.9 \pm 0.76 \mathrm{U} / \mathrm{L})$ with a significant decrease in serum albumin $(2.36 \pm 0.17 \mathrm{~g} / \mathrm{dl})$ and total proteins $(3.9 \pm 0.11 \mathrm{~g} / \mathrm{dl})$. However, coconut oil is effective in alleviation of alloxan induced disorders.
\end{abstract}

It is concluded that coconut oil is very effective against deleterious hyperlipidemic, hyperglycemic and nephro-toxic effects of alloxan.

Keywords: Hyperlipidemia, Diabetes, Cholesterol.

\section{Introduction}

Diabetes mellitus is one of the most common disease in the world. It is a metabolic disorder characterized by hyperglycemia. It occurred due to deficiency of insulin secretion or due to impairment of its action. Untreated diabetes mellitus causes several complications as hyperlipidemia, disorders in liver functions and diabetic renal dysfunction [1].

Alloxan is a chemical substance used in inducing diabetes in rats by destruction of the beta cells in pancreas that produce insulin. This destruction caused type 1 diabetes as it reduces the insulin production. The untreated diabetes mellitus causes numerous degenerative effects [2].

Virgin coconut oil is a vegetable origin oil which is well-known for its medicinal and nutritional value. It has high levels of saturated fatty acids. The two major fatty acids are lauric acid and myristic acid. Saturated fats that is rich in lauric acid, provide a favorable lipid profile and so, coconut oil helps in the prevention of cardiovascular atherosclerotic diseases. The consumption of coconut oil exhibits antiinflammatory, anti-oxidant, anti-bacterial, antiviral, antifungal, antipyretic and antidiabetic properties, [3]. Antioxidant properties and phenolic compounds as tocophenol and tocotrienol in virgin coconut oil aid in the prevention of many diseases. Virgin coconut oil increases high density lipoprotein cholesterol and reduces the level of low density lipoprotein cholesterol in serum and tissue [2]. Due to numerous degenerative effects of untreated diabetes mellitus on human health, researches 
have been done and still ongoing for management and treatment of diabetes mellitus.

Therefore, we attempted to study the possible protective effect of virgin coconut oil supplementation for in vivo alloxan-induced diabetes mellitus in rats.

\section{Material and Methods}

\section{Experimental animals}

Forty male albino rats with average body weight $125 \mathrm{gm}$ were used. Rats were obtained from the Experimental unit, Faculty of Veterinary Medicine, Benha University, Egypt. Animals were housed in separate clean metal cages. Fresh and clean drinking water was supplied ad libtium. The animals were left for 15 days for acclimatization before the beginning of the experiment. Rats were kept at constant environmental and nutritional condition throughout the period of the experiment.

\section{Alloxan add coconut}

Alloxan (Sigma Chemical Co., St. Louis, MO, USA). Coconut was purchased from the market.

\section{Induction of diabetes}

After two weeks of acclimatization of rats, alloxan monohydrate was injected once, intraperitoneally (150 $\mathrm{mg} / \mathrm{Kg}$ body weight) to induce type 1 diabetes at a dose of $150 \mathrm{mg} / \mathrm{kg}$ body weight intraperitoneally at one dose. After 3 days of administration, the fasting blood glucose level of these rats were measured. Rats with fasting blood glucose level above $200 \mathrm{mg} / \mathrm{dl}$ were considered diabetic.

\section{Preparation of virgin coconut oil}

Coconuts were purchased from the market. Wet extraction method was used [2]. The dry coconuts were broken manually, then its meat was scrapped and cut into small pieces. These cut pieces were ground in the grinding machine into viscous slurry, then it was squeezed through a clean piece of cloth to obtain coconut milk. The resultant coconut milk was left for about 24 hours to facilitate the separation of the emulsion as the crud could harden. Then the crud was scooped out leaving the pure virgin oil. The obtained virgin oil was collected into a bottle and stored at room temperature to be used in the experiment.

Oral glucose tolerance test (OGTT)

All groups were subjected to oral glucose tolerance test (OGTT) at the end of the $4^{\text {th }}$ week. The rats were fasted for sixteen hours and subsequently challenged with a glucose load of $2 \mu \mathrm{g} / \mathrm{kg}$ body weight. Blood glucose level were determined at 0 hour (before glucose treatment) and at 30,60, 120 and 180 minutes (after glucose reference).

\section{Sampling}

Blood samples were obtained from the retroorbital venous plexus. Blood was collected into plain centrifuge tube to separate serum for biochemical analysis (insulin, glucose, total cholesterol, high density lipoprotein cholesterol, triglycerides, urea, creatinine, ALT, AST, total proteins, and albumin).

\section{Determination of serum insulin level}

Serum insulin was estimated by EnzymeLinked Immunosorbent Assay (ELISA) using kit supplied by Diamond Diagnostics, Egypt according to manufacturer instructions.

Determination of serum glucose, ALT, AST, Total protein, Albumin, urea and creatinine

Serum ALT, AST, total protein, albumin, urea , creatinine, total cholesterol, HDL and triglycerides levels were estimated using kits supplied by Diamond Diagnostics, Egypt according to manufacturer instructions.

\section{Experimental design}

Forty male Wistar rats were randomly divided into four groups (10 animals per group). The first group is the control group. The second group is the alloxan group and it was given alloxan intraperitoneally at a single dose of 150 $\mathrm{mg} / \mathrm{kg}$ body weight,[1]. The third group (virgin coconut oil group) was given coconut oil orally $10 \mathrm{ml} / \mathrm{kg}$ body weight once daily for four weeks [2]. The fourth group (alloxan treated group) was given alloxan intraperitoneally at a dose of 150 $\mathrm{mg} / \mathrm{kg}$ body weight once then after three days, virgin coconut oil was given orally $10 \mathrm{ml} / \mathrm{kg}$ body weight for four weeks. Blood was collected for serum samples from the retroorbital venous plexus. It was collected from five rats in each group at the end of the experiment for evaluation of glucose level, insulin level, lipid profile, liver function tests and renal function tests.

\section{Statistical analysis}

Statistical analysis was performed using the statistical software package SPSS for Windows 
(Version 16.0, SPSS Inc., Chicago, Ill). The significance of differences between more than two groups was evaluated by one-way analysis of variance (ANOVA). If one-way ANOVA indicated a significant difference, then differences between individual groups were estimated using Fisher's least significant difference (LSD) test. Results are expressed as the mean \pm standard error of the mean (SEM). A $P$-value of less than 0.05 was considered significant[4].

\section{Results}

Initial blood glucose level after 3 days of induction of diabetes:

There was a significant increase in blood glucose level in alloxan group and in alloxan treated group when compared to control group and virgin coconut oil group (Table 1).

\section{Oral blood glucose level}

There was a marked increase in blood glucose levels in alloxan group after oral glucose administration and blood glucose level failed to return to normal values after two hours.
Meanwhile, following the administration of glucose, there was a minimal rise in blood glucose levels which returned to the normal control level after two hours in control group, virgin coconut group and alloxan treated group (Fig. 1).

Serum insulin, glucose, cholesterol, triglycerides, $H D L, V L D L$ and $L D L$ levels

Table 2 showed thatalloxan administration induced a significant decrease in serum insulin levels compared to control group, and this decrease was ameliorated in the presence of coconut oil. Also, alloxan group showed significant increase in the serum glucose, cholesterol, triglycerides, LDL and VLDL with significant reduction in HDL when compared with control group. Coconut oil group showed non-significant change in the serum glucose and cholesterol with a significant reduction in serum triglycerides, LDL and VLDL when compared to control group.HDL showed a significant decrease in alloxan group when compared to control and coconut groups. Meanwhile, there was a significant increase in HDL in coconut oil group when compared to control group.

TABLE 1. Initial blood glucose level after 3 days of induction of diabetes by Alloxan in Control, Alloxan, Virgin coconut oil and Alloxan treated oil groups (Mean \pm S.E.M) $(n=3-4)$

\begin{tabular}{lcccc}
\hline Parameter & Control & Alloxan & VCO & Alloxan treated \\
\hline $\begin{array}{l}\text { Initial blood glucose level } \\
\text { after 3 days of induction of } \\
\text { diabetes }\end{array}$ & $100.0 \pm 0.05^{\mathrm{a}}$ & $350.0 \pm 0.05^{\mathrm{b}}$ & $100.20 \pm 0.55^{\mathrm{a}}$ & $350.0 \pm 0.60^{\mathrm{b}}$ \\
\hline
\end{tabular}

Means with different superscripts within the same row were significantly different.

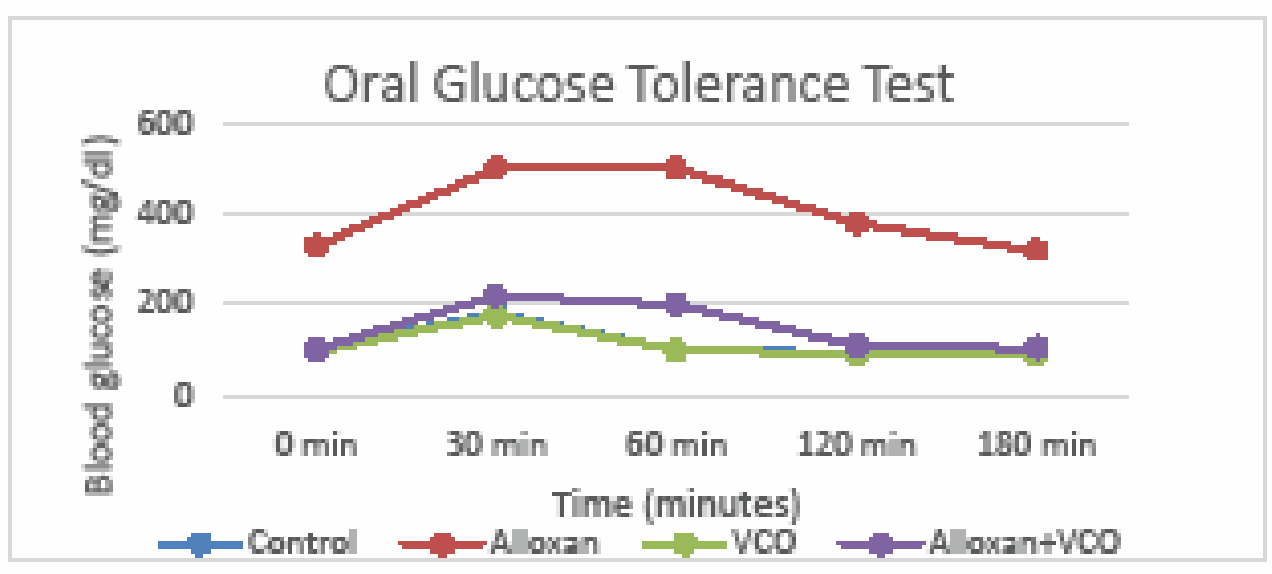

Fig.1. Oral blood glucose tolerance test of different experimental groups 
TABLE 2. Insulin, Glucose, Cholesterol, Triglycerides, HDL, VLDL and LDL in Control, Alloxan, Virgin coconut oil and Alloxan treated groups (Mean \pm S.E.M) $(n=3-4)$

\begin{tabular}{lcccc}
\hline Parameter & Control & Alloxan & VCO & Alloxan treated \\
\hline Insulin $(\mu \mathrm{iu} / \mathrm{ml})$ & $03.40 \pm 0.05^{\mathrm{c}}$ & $00.90 \pm 0.0^{5} \mathrm{a}$ & $03.20 \pm 0.05^{\mathrm{c}}$ & $03.00 \pm 0.05^{\mathrm{b}}$ \\
glucose $(\mathrm{mg} / \mathrm{dL})$ & $100.0 \pm 2.80^{\mathrm{a}}$ & $330.0 \pm 2.80^{\mathrm{b}}$ & $97.66 \pm 1.40^{\mathrm{a}}$ & $105.0 \pm 2.80^{\mathrm{a}}$ \\
Cholesterol $(\mathrm{mg} / \mathrm{dL})$ & $63.00 \pm 1.15^{\mathrm{a}}$ & $110.0 \pm 2.80^{\mathrm{c}}$ & $65.00 \pm 0.57^{\mathrm{ab}}$ & $70.00 \pm 0.57^{\mathrm{b}}$ \\
Triglcerides(mg/dL) & $200.6 \pm 1.40^{\mathrm{c}}$ & $350.0 \pm 7.05^{\mathrm{d}}$ & $120.5 \pm 2.50^{\mathrm{a}}$ & $150.0 \pm 4.04^{\mathrm{b}}$ \\
HDL-c $(\mathrm{mg} / \mathrm{dL})$ & $11.90 \pm 0.28^{\mathrm{b}}$ & $06.40 \pm 0.40^{\mathrm{a}}$ & $39.48 \pm 0.35^{\mathrm{d}}$ & $14.20 \pm 0.51^{\mathrm{c}}$ \\
VLDL-c $(\mathrm{mg} / \mathrm{dL})$ & $40.12 \pm 0.2^{8} \mathrm{c}$ & $70.00 \pm 3.40^{\mathrm{d}}$ & $24.10 \pm 0.50^{\mathrm{a}}$ & $30.00 \pm 0.80^{\mathrm{b}}$ \\
LDL $(\mathrm{mg} / \mathrm{dL})$ & $10.98 \pm 0.57^{\mathrm{b}}$ & $33.60 \pm 0.98^{\mathrm{d}}$ & $01.41 \pm 0.30^{\mathrm{a}}$ & $25.80 \pm 0.75^{\mathrm{c}}$ \\
\hline
\end{tabular}

Means with different superscripts with in the same row were significantly different.

Serum ALT, AST, total proteins, albumin, urea and creatinine levels

In Table 3, there was a significant increase in serum ALT, AST, urea and creatinine levels with a significant reduction in serum total proteins and albumin levels in alloxan group when compared to control group. Moreover, there was non-significant changes of serum ALT, AST, urea, creatinine, total protein and albumin in coconut group when compared to control group. On the other hand, a significant reduction of serum ALT, AST, urea and creatinine levels with a significant elevation in serum total proteins and albumin levels were found in alloxan treated group when compared with alloxan group. Serum ALT, AST, serum total proteins and albumin in alloxan treated group showed non-significant changes when compared with control and coconut groups.

\section{Discussion}

The Cocos nucifera $\mathrm{L}$ tree has medicinal and nutritional importance. Coconut is the unique source of natural substances for medicinal and industrial products. There are many products of coconut include coconut oil, coconut shell, raw kernel and tender coconut water. The tender coconut water and raw kernel are antioxidant, hypoglycemic, immunostimulant and antibacterial substances [5]. Virgin coconut oil is composed mainly of saturated fatty acids. The main fatty acids found are lauric, myristic and palmitic acids. Most of the fatty acids in virgin coconut oil are composed of medium chain fatty acids. So, they are directly absorbed by intestine and sent to liver to be used as energy source [6]. Therefore, virgin coconut oil is not stoked in adipose tissue and is not deposited in other organs like heart and liver and hence, it prevents atherosclerotic changes in the different body organs.
Furthermore, virgin coconut oil contains very small amount of cholesterol [7].

In this study, the administration of alloxan in rats in a single dose of $150 \mathrm{mg} / \mathrm{kg}$ body weight intraperitoneallyinduced diabetes. This is evidenced by significant increase in serum glucose level and significant reduction in serum insulin level than control group. It is due to destruction of the beta cells of the pancreas. This is due to generation of hydrogen peroxide, superoxide radicals and hydroxyl radicals. These radicals are responsible for death of beta cells resulting in a state of insulindependent alloxan diabetes[8]. This increase in serum glucose level and the reduction in serum insulin level are matched with the results obtained by Szkudelski [9] and Iranloye et al. [2]. On the other hand, the administration of virgin coconut oil resulted in a significant reduction in alloxan-induced elevation of serum glucose levels and a significant elevation in serum insulin levels. This revealed that virgin coconut oil ameliorates the damaging effect of alloxan on the beta cell of pancreas. These results matched with Iranloye et al. [2] and ensured that virgin coconut oil which contains lauric oil possesses insulino-tropic properties. This is evidenced by the reduction in the blood glucose level and the improvement in oral glucose tolerance test $[10,11]$. Oral glucose tolerance test is used to measure insulin function or the degree of peripheral utilization of glucose. results showed that following oral glucose administration, there was a minimal rise in blood glucose level which returned to the normal level after two hours in control, coconut and alloxan treated groups. Meanwhile, in alloxan group, there was a marked rise of blood glucose levels and it failed to return to normal levels after two hours. This is due to the insulino-tropic properties of coconut oil. results matched with Iranloye et al . [2]. 
TABLE 3. ALT, AST, Total protein, Albumin, Urea and Creatinine in Control, Alloxan, Virgin coconut oil and Alloxan treated groups $($ Mean \pm S.E.M $)(n=3-4)$

\begin{tabular}{lllll}
\hline Parameter & Control & Alloxan & VCO & Alloxan treated \\
\hline ALT(U/L) & $24.15 \pm 0.55^{\mathrm{a}}$ & $108.2 \pm 1.06^{\mathrm{b}}$ & $24.10 \pm 0.10^{\mathrm{a}}$ & $25.13 \pm 0.14^{\mathrm{a}}$ \\
AST(U/L) & $46.03 \pm 0.42^{\mathrm{a}}$ & $118.9 \pm 0.76^{\mathrm{b}}$ & $45.66 \pm 0.27^{\mathrm{a}}$ & $46.26 \pm 0.23^{\mathrm{a}}$ \\
$\mathrm{TP}(\mathrm{g} / \mathrm{dl})$ & $06.80 \pm 0.17^{\mathrm{b}}$ & $03.90 \pm 0.11^{\mathrm{a}}$ & $06.50 \pm 0.23^{\mathrm{b}}$ & $06.40 \pm 0.17^{\mathrm{b}}$ \\
Albumin $(\mathrm{g} / \mathrm{dL})$ & $03.21 \pm 0.06^{\mathrm{b}}$ & $02.36 \pm 0.17^{\mathrm{a}}$ & $03.30 \pm 0.11^{\mathrm{b}}$ & $03.13 \pm 0.03^{\mathrm{b}}$ \\
Urea $(\mathrm{mg} / \mathrm{dL})$ & $39.20 \pm 0.46^{\mathrm{a}}$ & $76.14 \pm 0.64^{\mathrm{c}}$ & $40.10 \pm 0.28^{\mathrm{a}}$ & $50.30 \pm 1.09^{\mathrm{b}}$ \\
creatinine(mg/dL) & $00.68 \pm 0.01^{\mathrm{a}}$ & $03.25 \pm 0.02^{\mathrm{c}}$ & $00.66 \pm 0.01^{\mathrm{a}}$ & $01.25 \pm 0.08^{\mathrm{b}}$ \\
\hline
\end{tabular}

Means with different superscripts with in the same row were significantly different.

Alloxan administration resulted in hyperlipidemia as a secondary complication of untreated diabetes. This is evidenced by a significant increase in serum cholesterol, triglycerides, LDL and VLDL with a significant decrease in HDL than the control group. The elevation of the levels of serum cholesterol, triglycerides, LDL and VLDL after alloxan administration is consistent with results of add $[12,13,14]$ which is due to alloxan mediated free radicals that induce lipid peroxidation and damage of organs membranes. The increased cholesterol levels may be due to the increased activity of 3-Hydroxy -3- Methyl Glutaryl- Coenzyme A reductase which is the rate limiting factor in cholesterol biosynthesis [15]. The increase of the levels of VLDL is due to high levels of free fatty acids and hyperglycemia and also due to the reduction in activity of lipoprotein lipase resulted in decreased clearance of VLDL and LDL [16].

On the other hand, virgin coconut administration resulted in a significant reduction in alloxan-induced elevation of serum cholesterol, triglycerides, VLDL and LDL levels and a significant elevation in serum HDL levels. This revealed that virgin coconut oil ameliorates the damaging effect of alloxan on the lipid profile. These results matched with Shariq et al. [17]. Virgin coconut oil contains tocopherols and beta carotene. Increased beta carotene increases the fecal secretion of bile acids and decreases the concentration of lipids [2]. Moreover, virgin coconut oil contains high level of phytosterol. This phytosterol competitively blocks the absorption of cholesterol and increases the fecal excretion of bile acids and neutral sterols thus it improves the circulating lipid profile [16]. Virgin coconut oil decreases the triglycerides levels which may be due to its composition of mainly short and medium chain fatty acids which are transported directly to liver to be excreted [18].

Table 3 showed that administration of alloxan resulted in renal and hepatic injuries which is reported by significant elevations in serum ALT, AST, urea and creatinine level with a significant decrease in total proteins and albumin in alloxan group when compared to control group. Meanwhile, virgin coconut oil alleviated these injurious effects induced by alloxan. This ensured that coconut oil removed the liver and renal cell damage. Results matched with those who ascertained that virgin coconut oil is efficient in alleviation the alloxan induced renal dysfunction [1]

\section{Conclusion}

This experimental study was designed to assess the effect of virgin coconut oil in the alloxan induced disorders and it is concluded that virgin coconut oil is effective in alleviation hyperglycemia, hyperlipidemia, renal and hepatic dysfunctions induced by alloxan.

Acknowledgements: The authors appreciate the efforts of all those participated in this study.

\section{Conflict of interest}

We certify that there is no conflict of interest with any financial organization regarding the material discussed in the manuscript. I agree for copyright transfer according to the journal policy.

\section{$\underline{\text { References }}$}

1- Akinnuga, A.M, Jeje, S.O., Bamidele, O. Virgin Coconut oil: Remedial Effects on Renal Dysfunction in Diabetic Rats. Physiology Journal, 38, 11-16 (2014). 
2- Iranloye, B., Gabriel, O. and Olubiyi, M. Anti-diabetic and antioxidant effects of virgin coconut oil in alloxan induced diabetic male sprague dawley rats. Journal of Diabetes Mellitus, 3, 221- 226 (2013).

3- Santana, L.F., Cordeiro, K.W., Soares, F.L. Coconut oil increases HDL-c and decreases triglycerides in wister rats. Acta Scientiarum, 38, 185- 190 (2016).

4- Kinnear, P. and Gray, C. SPSS 12 made simple (Psychology) 2006.

5- DebMandal, M. and Mandal, S. Coconut (Cocos nucifera L.: Arecaceae): in health promotion and disease prevention. Asian Pac J Trop Med. 3, 241247 (2011).

6- Boemeke, L., Marcadenti, A., Busnello, F.M. Effects of coconut oil on human health. Open Journal of Endocrine and Metabolic Diseases, 5, 84- 87 (2014).

7- Vasudevan, D.M. Coconut oil and health controversy. International Journal of Health and Rehabilitation Sciences, 2, 157- 164 (2013).

8- Lenzen, S. The mechanism of alloxan- and streptozotocin- induced Diabetes. Diabetologia, 51, 216- 226 (2008).

9- Szkudelski, T. The mechanism of alloxan and streptozotocin action in B cells of the rat pancreas. Physiological Research, 50, 536- 546 (2001).

10- Siddalingaswamy, M., Rayaorth, A. and Khanum, F. Anti-diabetic effects of cold and hot extracted virgin coconut oil. Journal of Diabetes Mellitus, 1, 118123(2011).

11- Sheela, D.L., Nazeem, P.A., Narayankutty, A., Shylaja, R.M., Davis, S.P., James, P., Valsalan, R., Davassy, B.T. and Raghavamenon, A.C. Coconut phytocompounds inhibits polyol pathway enzymes: Implication in prevention of microvascular diabetic complications. Prostaglandins Leukot Essent Fatty
Acids, 127, 20-24 (2017).

12- Sarker, M.R. Antihyperglycemic, insulin-sensitivity and anti-hyperlipidemic potential of Ganoderma lucidum, a dietary mushroom, on alloxan- and glucocorticoid-induced diabetic long-evans rats. Functional Foods in Health \& Disease, 5, 450- 466 (2015).

13- Sultana, S., Akter, S. and Khan, M.I. Antihyperlipidemic action of Zingiber officinale (Ginger) Juice in alloxan induced diabetic rats. Ibrahim Med. Coll. J., 6, 55- 58 (2012).

14- Abdulazeez, S.S. Freeze dried strawbrry powder ameliorates alloxan induced hyperlipidemia in diabetic rats. Biochemical Research, 26, 77- 81 (2015).

15- Rashid, K., Das, J. and Sil, P.C. Taurine ameliorate alloxan induced oxidative stress and intrinsic apoptotic pathway in hepatic tissue of diabetic rats. Food Chem. Toxicol., 51, 317- 329 (2013).

16- Sheriff, S.A. and Devaki, T. Lycopene stabilizes lipoprotein levels during d-galactosamine/ lipopolysaccharide induced hepatitis in experimental rats. Asian Pac. J. Trop. Biomed., 2, 930- 934 (2012).

17- Shariq, B., Zulhabri, O., Hamid, K. Evaluation of anti-atherosclerotic activity of virgin coconut oil in male wister rats against high lipid and high carbohydrate diet induced atherosclerosis. $U K$ Journal of Pharmaceutical and Biosciences, 3, 1014 (2015).

18- Ooyama, K., Wu, J., Nosaka, N. Combined intervention of medium- chain triacylglycerol diet and exercise reduces body fat mass and enhances energy expenditure in Rats. Journal of Nutritional Science and Vitaminology, 54, 136- 141 (2008).

(Received 14/04/2017; accepted 24/07/2018) 


$$
\begin{aligned}
& \text { التأثيرات المضادة لمرض السكرى ومضادات الاهون لزيت جوز الهند البكر في الجرذان }
\end{aligned}
$$

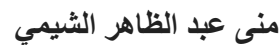

$$
\begin{aligned}
& \text { قسم الباثولوجيا الإكلينيكية ـ كلية الطب البيطري - جامعة بنها - مصر. }
\end{aligned}
$$

من المعروف ان زيت جوز الهند البكر لها آثار صحية مفيدة. وعلى الرغم من أنها غنية بالأحماض الدهنية

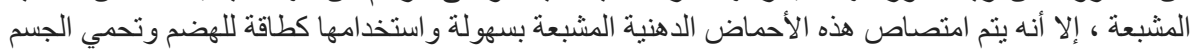

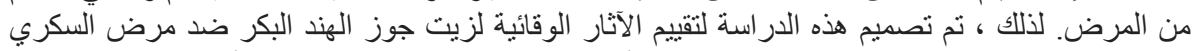

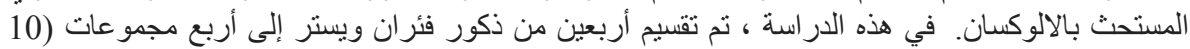

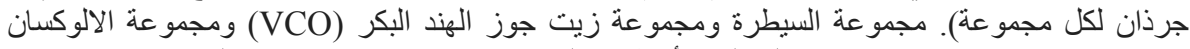
(Alloxan)

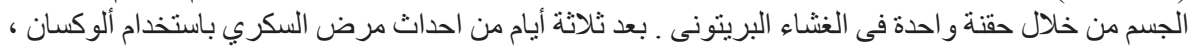

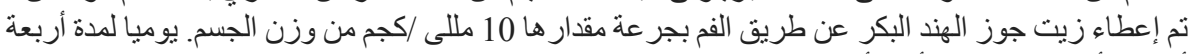

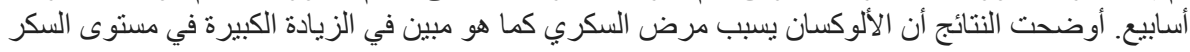

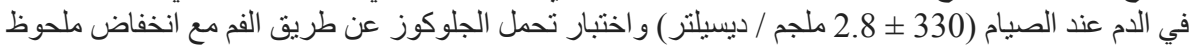

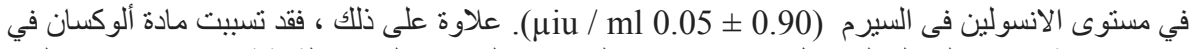

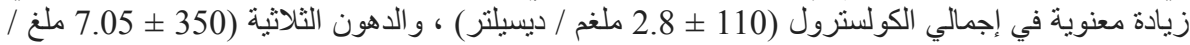
ديسيلتر و و أيضا الخلل الوظيفي الذب يحدث بسبب زيادة كبيرة

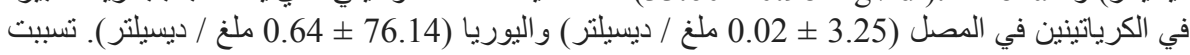

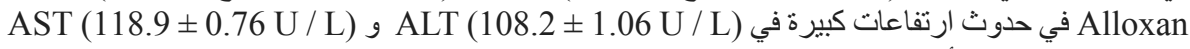

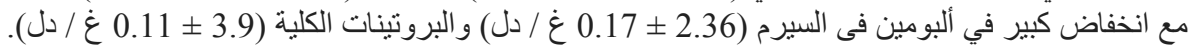

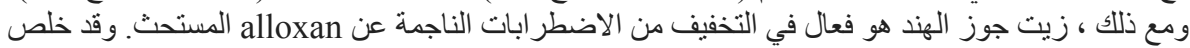

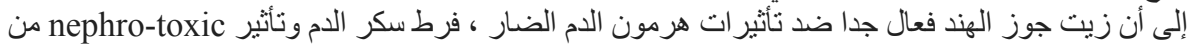
alloxan 